\title{
Between family and temple: Jesus and sacrifices
}

\author{
Adriana Destro and Mauro Pesce ${ }^{1}$ \\ Dipartimento di studi linguistici e orientali \& Dipartimento di discipline storiche \\ University of Bologna \\ Research Associates: Department of New Testament Studies \\ University of Pretoria
}

\begin{abstract}
Sacrifice generally aims at obtaining from and by supernatural force the right to exercise control over life. As far as Jewish sacrifices are concerned, according to Leviticus, victims' blood serves to purify the holy places of the temple and no sacrifices can expiate voluntary sins. In Mt 6:12 God's forgiveness is obtained through a trilateral relationship between the sinner, the "debtor", and God, without any expiatory sacrificial act being required. Jesus did not, however, reject the sacrificial rituals of the temple, those rituals that did not serve to expiate voluntary sins. In Jesus' proposal, the forgiveness by one individual of another implies a social conception, which includes the absence of debt, reconciliation, justice and equality. Jesus transforms and relocates two aspects of the religion of the Second Temple. In his conception, the forgiveness of sins and a new beginning of people's lives brought about by the Jubilee can happen anywhere (not only in the temple) and at any time (not only once a year for Yom hakippurim).
\end{abstract}

\section{INTRODUCTION}

Since the last decades of the nineteenth century an uninterrupted and extensive scholarly debate has been devoted to the definition of sacrifice. To date, a number of ethno-

\footnotetext{
1 Paper presented at the International Context Group Meeting at the University of Pretoria, June 2001. Prof Dr Adriana Destro and Prof Dr Mauro Pesce visited South Africa as research associates of Prof Dr Andries G van Aarde, Department of New Testament Studies, Faculty of Theology, University of Pretoria.
} 
graphical studies and scientific conferences have focused on the subject of sacrifices. ${ }^{2}$ This is indicative of the great complexity and relevance of specific themes around which the scientific discussion has revolved.

In our presentation, this consciousness leads us to take into account some preliminary and substantial questions. First (a), we need to start analyzing general theories dealing with sacrificial rituals. Secondly (b), we must try to determine the nature of first century Jewish sacrifices in the Land of Israel. At this point it will be necessary (c) to construct a model, taking into account some of the numerous features of sacrifices brought to light by theoretic discussion and historical research.

The history of the research carried out to date has convinced us that models which would be valid for all times, and for all occasions, are not available. Any modeling can be integrated and modified, since definition and use of concepts unavoidably have a historical nature and as a result a number of cultural limits. This leads to an inevitable consequence: the same phenomenon may be analyzed simultaneously through different approaches and models. Given this range of possibilities, any analysis may pick up on different or complementary aspects, when different or complementary frames or data treatments are utilized.

Two recent essays, an anthropological analysis (Destro 2001) and a historical one (Pesce 2001) form the point of departure of this contribution. The first of the two, Il dispositivo sacrificale. Strumento della morte e della vita ["The sacrificial device: An instrument of life and death"], examines (a) the need for a general theory of ritual (as starting point for the analysis of sacrifices); (b) the need for a theory of culture and society (a view of concrete social and cultural features within which sacrifices exercise their functions) and (c) the need for an interpretation of sacrifices that moves from the

2 I recall two meetings organised at the Taubes Center in Israel by Albert Baumgarten. The proceedings are about to be published by Brill of Leiden. In 1995 a conference was held in Heidelberg entitled Opfer: theologische und kulturelle Kontexte (Internationales Symposium 19-21 Oktober, 1995), the proceedings of which will be published by Kohlhammer of Stuttgart. The "Italian Center of Advanced Studies on Religions" in Bertinoro has organised a national biennial research programme on Jewish and Christian sacrifice in the context of Hellenistic-Roman religions, of which the proceedings are published in the Journal Annali di Storia dell'Esegesi 18/1 (2001) and 19/1 (2002). In June 2001 a conference was held in Paris with the aim of appraising the state of research on sacrifice thirty years after the publication of the celebrated volume by M Detienne and J P Vernant, La cuisine du sacrifice (1979, Paris). On rituals and sacrifices see also Bonte 1993; Brisbarre 1998; Burkert 1972; Chelhod 1955; Combs-Shilling 1989; DestroPesce 1995, 1997, 2001a.; Dorival 2001; Grottanelli 1988; Rappaport 1999; Stowers 1995. 
hypothesis that "control over life" is one of their basic targets. The second essay, Gesù $e$ $i$ sacrifici ebraici ["Jesus and the Jewish sacrifices"], shows (a) that in Leviticus sacrifices have a multiplicity of functions; (b) that sin offerings expiate only inadvertent sins and that in the first century CE there was an already long-standing debate on the ritual of expiation for voluntary sins (Yom ha-kippurim); (c) that Jesus accepted the Jerusalem Temple sacrifices, but that he assigned no function to the Temple or to Yom ha-kippurim as far as the expiation of voluntary sins was concerned.

\section{THEORIES AND GENERAL CATEGORIES}

Let us consider a general question to commence with, namely: would the historical or anthropological theories on sacrifices, which are currently available, be useful insofar as knowledge about Jesus' attitudes towards sacrificial rituals is concerned? To rephrase the question, would it be very misleading to begin an analysis of Jesus' attitude, without giving a summary review of some theoretical positions about sacrifices? With such considerations in mind, we advance a few observations on some recent assertions.

\subsection{Valeri's "preliminary definition"}

By sacrifice I mean any ritual action that includes the consecration of an "offering" to a deity. This offering is made up of one or more individuals belonging to species having symbolic values exploited in the course of the ritual. ... Usually the offering, after having being entirely consecrated to the deity, is divided in two parts: the first goes to the deity alone, the second goes to the sacrificer and the other participants, among whom it is shared according to the order of their rank.

(Valeri 1985:38)

He suggests that: "Every sacrifice must be described as a function of the following features: (1) its end and the occasion on which it is made; (2) the deity or deities to whom it is addressed; (3) the content of the offering and its symbolic value; (4) the way the offering is treated and apportioned in the rite." 
This definition allows Valeri to indicate the aspects which should be concentrated on in any analysis of sacrifices: "The ends and occasions of sacrifices as well as the offering's symbolic values and treatment [should] receive particular emphasis as the features that best make it possible to discover the fundamental principle of sacrificial action." (Valeri 1985:38). Valeri's last statement is particularly worthy of attention, because it emphasizes the range of ends, contents and treatments associated with sacrifice. He stresses the great variety of occasions on which sacrifices are practiced in all cultures. ${ }^{4}$ Indeed, too often the theoretical models of sacrifice neglect the fact that individual sacrifices have functions which clearly differentiate them from one another (within each culture), and they result in positing a theory based only on a certain type of sacrifice: for example, in the case of Jewish culture, the sacrifice for sin (hattat) or in other cases, the sacrifice of communion (zebah shelamim), are more discussed to the detriment of others.

Some years later, Valeri (1994) formulated a second definition of sacrifice, which Grottanelli (1999:14) summarized as follows: "In its fully developed form, the ritual [of sacrifice] includes the following acts, in the following order: 1) induction 2) the killing 3) the renunciation ${ }^{5}$ and finally 4) the consumption". ${ }^{6}$ Grottanelli (1999:14) stresses the importance of the latter aspect of Valeri's theory, namely enjoyment. In this light sacrifice, is defined as: "the ritualized taking away of life (or the destruction/ removal from the sphere of the purely human use, of precious objects, understood as marks of life), to obtain some benefit."

3 Valeri's definition seems to leave the performative dimension of sacrificial ritual too implicit. It is not enough to restrict oneself to saying that the phase of the inducement of the offering, and of its transfer from a profane to a sacred environment is necessary. It is necessary to discover explicitly the moment of the dislocation of the offering from the profane to the sacred environment, and all the ritual practices that are necessary for this dislocation to occur. For example, in the ancient Jewish sacrificial ritual, the sheep were not merely chosen and carefully examined according to patterns, which also imply specific symbolic meanings, but they had to be subjected to special treatment, for example being washed, before being allowed to enter the sacred place.

4 See his list in Valeri (1985:38-44).

5 That is "the cutting away and removing a part of the victim (and sometimes of the whole victim)" from human consumption, that does not necessarily imply "a giving to from a giving up" (Grottanelli 1999:14).

6 "The more social and festive part of the ritual, and often, the culmination of the sacrifice" (Grottanelli 1999:14). 
Briefly, what seems interesting in Valeri's definition is his focus on (a) various types of sacrifice in the same society, (b) several features present in every sacrificial action and (c) different existential or social situations requiring a sacrifice. Moreover, Valeri is referring to ancient Hawaiian society, thus dealings with (d) a concrete society: his "theory of ritual", therefore, cannot be seen as extraneous to or divorced from the specific culture in which the ritual is practiced. This illustrates that generalizations can be arrived at only by starting from specific ethnographical cases. ${ }^{7}$ Valeri confronts us with what Bourdieu defines the problem of "taking into consideration a specific cultural area with the aim of finding out what does not vary in the variety observed, i.e. the structure." (Bourdieu 1995:14.)

\subsection{Malina's definition}

In The New Testament World: Insights from Cultural Anthropology (1993), Malina's point of departure is the perspective that the process of sanctification and that of sacrifice correspond to two stages or phases, which take place at different times. The first is the process of sanctification which constitutes the "presupposition of sacrifice": "The process ... of setting persons and things apart from or for God is called sanctification .... The process of interacting with God by means of persons and things thus set apart is called sacrifice" (Malina 1993:168). In order to understand the process of sanctification, Malina is clearly referring to Van Gennep' three phases (separation, marginalization, and aggregation), and is speaking of "zones of interaction" between human beings and deities. He conceives the process of sanctification both in terms of space and time. ${ }^{8}$ Malina sees the sacrificial interaction with God primarily as a patron-client relation:

7 "L'éthnologue ne réfléchit à sa compréhension des autres cultures que par le principe de différenciation épistémologique, à savoir selon l'oscillation pendulaire des comparaisons, différences et contrastes, entre elles et avec la sienne" (Affergan 1997:61).

8 "The way you set apart or sanctify things is by moving them from their world (or nobody's world in our limitless-good culture) to your world (Malina 1993:168)". "Sanctification ... consists of three phases which might be depicted as follows. Passage from a normal condition considered "profane to you" through a marginal condition in which the object is considered "potentially yours" to a new normal condition in which the object is considered as "sacred to you" (Malina 1993:167). 
Sacrifices to God are analogous to gifts given to higher-class patrons. What patrons want of their clients is recognition of honor, submission, a following. Sacrifice to God symbolizes a gift of a client to a patron, an expression of an asymmetrical but reciprocal relationship with a view to power, protection, and the joy of basking in the presence of the patron of patrons ... The object is taken by the ritual leader of the intermediate or marginal zone, who acts as a bridge within the donor space and the space of God, space that symbolizes their worlds. By means of this bridge and the activity of the marginal zone, the benefits of the patron pass to the donor, who may be an individual, a group, or the nation at large.

(Malina 1993:170-171)

Malina notes that in order to understand the Jewish sacrifice of the first century CE, it is necessary to examine the nature of the social processes of Judean society of the time (Malina 1996:27). ${ }^{9}$ The dominant social relation in this case - as he previously pointed out (Malina 1993:170) - is that of patron-client, centering on a social group. The purpose of sacrifice, according to Malina, is therefore to maintain the "assigned and inherited social status" of people through the protection of "patrons" belonging to higher social strata $(1993: 170){ }^{10}$

Briefly, in our opinion, the useful features of Malina's scheme are: (a) the distinction between sanctification and sacrifice, (b) the need to understand the meaning of sacrifice in the light of the social relations of a specific culture, (c) the strict relation between a theory of ritual and a theory of culture, and (d) a definition of Jewish sacrifice.

A few years later, in 1996, Malina dealt more systematically with sacrifice in general, and Jewish sacrifice in particular, within the framework of Greek and Roman Mediterranean religions. He formulated a new definition of sacrifice according to which "sacrifice is a ritual in which a deity or deities is/are offered some form of inducement,

9 "To discover the meaning of any line of behavior for persons performing the behavior, it seems one must necessarily have recourse to the social system of those persons" (Malina 1996:27).

10 In addition, sacrifice is seen as a communal meal offered by the patron: "The fellowship of the Temple meal clearly symbolizes the fellowship of the benign patron with his clients" (Malina 1996: 171-172). To invoke the patron-client model means invoking a specific kind of share-meal (cf Crossan 1998:427), who distinguishes between "patronal share meals", "communal share meals", and "societal share meals". In the former, a wealthy man hosts the entire community. This is the typical house-church situation. 
rendered humanly irretrievable, with a view to some life-effect for the offerer" (Malina 1996:37). For each part of his definition Malina offers the following meaning:

[a] A ritual, sacrifice deals with social lines in some way. It is by means of these lines or boundaries that people get to understand where things fit, so that society makes sense. Sacrifice is always about these lines or boundaries. [b] The deity is always some ultimate. All that accounts for and embraces the human drive to make sense out of all human experiences. [c] Inducement includes the goods or services that are directed at the deity with a view to having an effect. [d] Rendering the mediating entity irretrievable transforms it into an irrecoverable form: killing, baking, pouring out, burning salt, incense. [e] The effect sought in sacrifice is a life-effect: the maintenance or restoration of life, ascribed solely to the deity .... Life-maintenance sacrifices celebrate life in festivity. Life-restoration sacrifices revitalize after accidental deviance, or after stepping outside the human realm: mother in the realm of the prehuman; husband/son in the realm of the dead. ${ }^{11}$

(Malina 1996:38)

The novelty of the 1996 definition most relevant to the present discussion, lies essentially in point [e], affirming that the effect of the sacrifice is a life-effect, and that there are two kinds of sacrifice with such effect. It should be noted that, with regard to Israelite animal offerings, Malina (1996:35) specifies that "(i)n Israel ... there is a gradual constriction of domestic sacrifice." This reflection seems especially significant for elucidating the meaning of the Leviticus sacrifices.

What is distinctive of Israelite sacrifice in its Levitical reformulation is that it is confined to the Jerusalem Temple. This makes all sacrifice political sacrifice, with God understood in political terms. He is no longer "patron" (a

11 Another important aspect of Malina's theory is that "in sacrifice, as religious elites know, there is really no guarantee of balanced repayment. The reason for this is that the interacting partner in sacrifice is a person in control and the effect sought in sacrifice is a life-effect" (Malina 1996:38). The use of the offering is different in the two different sacrifices: "the deity or deities receive their portion, a part in the case of life affirmation to be shared with the sacrificing circle; whole in the case of the restoration" (Malina 1996:39). 
kinified relationship), but "king" or "lord" (a politified relationship). With the politification of religion, the Levitical reform comes to dominate domestic religion as secondary.

(Malina 1996:35-36)

On the basis of his newly acquired positions, Malina significantly integrated his previous definition of sacrifices in the third edition of New Testament World: Insights from Cultural Anthropology. The example of the evolution and enrichment of Malina's thinking confirms that any model can be changed and adapted to new research developments.

\subsection{Eilberg-Schwartz's interpretation of Jewish sacrifice}

More than a decade ago, Eilberg-Schwartz, in Savage in Judaism, attempted an anthropological interpretation of Jewish sacrifice. He did not devote many pages to the subject. In his book, the theme of sacrifice appears within a series of reflections on human sins and the expiation thereof. Eilberg-Schwartz's language and categories however reflect an approach to the topic of sacrifice that has found favour among a number of contemporary scholars. His basic idea is that: "The very premise of the sacrificial system is that God will permit Israelites to sacrifice animals instead of sacrificing themselves and their children" (Eilberg-Schwartz 1990:135). The cultural premise is that of substitution: "The sacrificial system rests on the idea that an animal's life is a substitute for the life of the person who brings the animal to be slaughtered" (Eilberg-Schwartz 1990:134).

The discourse of substitution is accordingly connected to a parallel between animals and human beings: "The dependence of the sacrificial systems on the metaphorical relationship between Israelites and their herds and flocks explains why only animals from their herds and flock can be used as offerings" (Eilberg-Schwartz 1990: 135). Most interesting here is the fact that Eilberg-Schwartz develops his analysis by offering an image of ancient Israel as a pastoral society, and by taking this pastoral type of life as an influential setting for many of the Israelites' social relationships. Thus, his attention is focused on those animals belonging to the domestic flock or herd, which as 
such, was closely related to people's material and symbolic life. On this basis, animals may be considered as directly reflecting specific moments of the Israelites' ordinary life. Any action performed on them can be regarded as if performed on people. EilbergSchwartz, however, restricts himself to an analysis of a small segment of the sacrificial system. Defining animals as substitute for the offerer, he neglects the confirmatory or transformative effects of the sacrifice. ${ }^{12}$ On the other hand, what remains important in Eilberg-Schwartz's thesis is that sacrifice is strongly linked to life. It is related to the equivalence of lives and to the exchange of the life of the sacrificed animal for the life of the offerer.

Furthermore, elaborating on his theory, and concurring with Milgrom (1991), Eilberg-Schwartz confirms that the Leviticus sacrifices concern inadvertent sins. "The substitution only appeases God for relatively minor sins, such as unwittingly violating a law (Lev 4); for heinous crimes, such as murder, God demands the person's life" (Eilberg-Schwartz 1990:136). Sacrifice, therefore, does not bring about expiation for the most serious sins, those committed in full consciousness. This means that sacrifice is not a mechanism that resolves all the problems of life and of death. It should however be borne in mind that Eilberg-Schwartz's passage has a very specific objective, and that it does not refer to the question of sacrifice in general, nor does it set out to analyse the various types of Jewish sacrifice and their different functions.

\subsection{Mary Douglas' anthropological theory of Jewish sacrifice}

A few years ago, Mary Douglas (1998) advanced an anthropological theory of Jewish sacrifice as it appears in Leviticus (cf also Douglas 1993, [1993] 2001, [1993] 1994, 1966, 1996). This theory is neither a general interpretation of sacrifice, nor an approach to all biblical sacrifices. According to Douglas, in Leviticus "the act of sacrifice is less a killing than a transformation from one kind of existence to another" (Douglas 1998:69). Douglas hereby expresses the idea that any sacrifice modifies life. From her words it appears that physical and symbolic modifications are intrinsic to the act of imposing

12 He tries to understand on the basis of cultural images which animals could be considered "substitutes" for the person deserving death, but he seemingly does not want to formulate a comprehensive theory of the sacrificial ritual. 
death on a living being. Once burned, the victim is transformed into smoke, which ascends towards God. ${ }^{13}$

(a) It must be noted that, in her theorizing on sacrifices, Douglas primarily focuses on the victims' bodies ${ }^{14}$. She assumes that sacrifices attain meaning by human actions on animal bodies, that is, through the way in which animals are ritually treated. In particular, she envisages inner and outer parts of the animal, their specific or reciprocal order, and how they are used on the altar:

The first chapters of Leviticus are largely about how to make a sacrifice ... To find the underlying logic we have to look carefully at what it says about bodies and parts of bodies, especially what is inner or outer, on top and underneath, and pay special attention when it emphasizes by frequent repetitions and strong prohibitions.

(Douglas 1998:69)

Thus, Douglas renders her interpretation explicit: the body of the sacrificial animal is thought of as a microcosm. In other words, the authors of Leviticus regarded the anatomy of the animal as a reflection of the cosmic order established by God.

Being convinced that the body of the sacrificial animal may be conceived as a microcosm, Douglas concentrates her attention on the quartering of the animal. She minutely analyses the ritual use of the parts of the quartered animal and stresses the importance of the placement of the parts on the altar because, in her opinion, this is the action that clarifies some essential assumptions in Leviticus. In particular, she emphasizes the central importance of the fat around the vital parts (she believes that such fat is no less important than the blood) ${ }^{15}$ :

13 This would be demonstrated, in Mary Douglas' opinion, by the fact that Leviticus repeats 11 times that with the act of sacrifice "the priest 'turns all the offering into smoke' (Lev 1:9, 13, 17; 2:16; and repeated 3:5, 11, 16; 4:10, 26, 31,35)" (Douglas 1998:68).

14 On some specific social meanings of body's treatments in Judaism see Destro (1994).

15 She establishes an important parallel between forbidden blood and forbidden fat: "the rule against eating suet is paired with that for blood: the people of Israel are prohibited from eating suet in the same strong terms as they are forbidden to eat blood (Lv 3:16-17; 7:22-26)" (Douglas 1999:71). She is, however, primarily interested in the prohibition of the fat and ends up by saying relatively little about blood. 
Suet is not to be confused with ordinary animal fat .... The suet lies over and around the seat of life, the seat of thought and emotion ... Suet is found ... in a middle zone over and around the kidneys and over the entrails ... The vital pieces of anatomy (kidneys and liver lobe) which have been selected for a special consecration on the alter are found in the body engulfed in the suet which lies around the diaphragm. The suet separates the entrails, which comprise the seat of thought and emotions and the semen which is the seat, the principal of fertility, from the upper part which in the live animal is accessed through throat and mouth.

(Douglas 1998:71, 72, 73, 74)

(b) Douglas further defines the overall action of the sacrificial ritual as:

a game of building blocks in which God is the player and the object is to rearrange the dismembered body so as to model some divine construction of the universe and a teaching about life and death. In this architectural game rules about positioning, such as 'over' or 'under', are necessary for interpreting not only sacrifice, but the whole book. In a diagram, position is everything; in a sacred text, the prohibitions that set things apart are crucial.

(Douglas 1998:75)

A correspondence, even a strong interconnection, between the two orders is evident: each order answers to the other. Together they make the supreme order explicit: "Two kinds of ordering are in play, one the arrangement of the internal parts of the living being, that is, the normal order of the animal's anatomy, and the other, their order on the altar. For the altar in every case the middle zone, the suet or fat area, is taken out first and burnt on the altar" (Douglas 1998:76).

(c) To understand how the Leviticus sacrifices expiate sins, Douglas takes recourse to a specific anthropological interpretation of ancient sacrifice. She believes that in almost 
all religions, sacrifice has an indissoluble connection with oracles. ${ }^{16}$ Only after an oracular response would it be known which sacrifice had to offered to remedy misfortune:

Divination is the institution that usually links sin, misfortune, and sacrifice. There is some misfortune, the oracle finds the causes and prescribes the remedy, a sacrifice. There are also judicial problems which are commonly solved by oracle, for example to find the truth between contending parties or to support an appeal from an unacceptable verdict .... [F]ar from being a snare and a sin, divination actually meets a demand for truth.

(Douglas 1998:110, 111-112)

On the contrary, Douglas maintains that Leviticus marks a break between sacrifice and oracles, which were forbidden at a certain point in the evolution of the Jewish religion. She affirms that "Leviticus is full of phrases ambiguous to us now but which make sense if restored to an original context of oracles and retaliatory justice" (Douglas 1998:123). She openly recognizes that "unwitting sins are the only kind of sin which call forth the rituals of sacrifice" (Douglas 1998:125). The reason for this restriction would lie in the original connection of sacrifice with oracle. Originally, the law about inadvertent sins aimed to prevent the response of the oracle from being challenged:

The Law of sin offerings says that regardless of your knowledge or intentions, when you have discovered (by divination), what you did wrong, you must make restitution plus one fifth of the value of things stolen, and pay up a ewe lamb, or a she-goat or a bird so as to get atonement done for your sin. Whether you knew about it or did not know about it is irrelevant, the oracle has convicted you and you must do the ritual. By this device arguing and protesting innocence can quickly be dismissed, and the validity of the oracle is not brought into question.

16 To speak of sacrifices without speaking of oracles "would be like using a pharmacopoeia to describe a medical system, giving only the names of the ailments and the medicine and nothing about the diagnostic process" (Douglas 1999:109). 
Therefore, she can claim that:

There was no doctrinal distinction between witting and unwitting sins, the regular mention of "unwitting" was not a theological but a practical matter. The oracle would be brought into action when matters came into the jurisdiction of the priests. "Unwitting" would merely be a convenient term for the principles of brushing aside the usual endless protestations against the oracular verdict. ${ }^{17}$

(Douglas 1998:127-128)

In conclusion, for the purposes of our research, Douglas has the merit of having illustrated more than anyone else, the principle of cosmic order being expressed in the body of the victim, recomposed on the altar through sacrifice. She herself claims: "The central idea of this book is that Leviticus exploits to the full an ancient tradition which makes a parallel between Mount Sinai and the tabernacle" (Douglas 1998:59). "[S]acrifice is one of the main figural motives with which it presents the principles of God's Creation and the divine order of existence" (Douglas 1998:66).

It nevertheless seems to us that her underlining of the "figural" meaning of the sacrifice leads her to attribute less weight to the transformative effect of the ritual, though she did raise the matter from the beginning. Her ingenious solution to deny that sacrifices were limited to the expiation of inadvertent sins, in reality is only based on certain cases in chapter 5 of Leviticus.

\subsection{Theories on sacrifice - findings}

At the end of this overview of theories, we would like to point out that sacrifice is always a complex ritual action. It generally aims at obtaining from the divinity (or any supernatural force) the right to exercise control over life (and/or to reduce the threat of

17 This does not stop her from accepting Milgrom's (1991) explanation, which she calls "psychological": "there are two possible explanations, which do not conflict with each other, a psychological one and an anthropological one" (Douglas 1999:125). Milgrom "elaborates on 'the priestly doctrine of repentance' ... repentance mitigates crimes against God such as false oaths. Repentance alone is not enough, there must also be sacrifices. Since all sins, however grave, can be classed as unwitting if remorse and repentance follow, a benign technicality allows them all to be forgiven" (Douglas 1999:126). "Conscience, as Milgrom says, is recognized by the priestly writer as "a legal force which can convert a deliberate sin against God, always punishable by death, into an involuntary sin, now expiable by sacrifice" (Douglas 1999:126). 
death). Killing and offering an innocent victim is the instrument, culturally regarded, to receive from supernatural forces the right - exclusively reserved to them - to exercise such control.

As far as Jewish sacrifices are concerned, according to Leviticus, (a) victims' blood serves to purify the holy places of the temple and, thus, enables God to be permanently present in the Temple of Jerusalem (thus guaranteeing the effectiveness of all rituals taking place there); (b) there are various categories of sacrifices, but only one of these categories serves to expiate inadvertent sins; (c) there are no sacrifices that can expiate voluntary sins. Voluntary sins are subject to civil and penal law, as well as being subject to the punishment of God, and are cancelled by the annual ritual of Yom hakippurim. However, there are different ways of understanding how the ritual of Yom hakippurim expiated the voluntary sins. There is also evidence that during the Second temple a degree of uncertainty or discussion existed over some aspects of its effectiveness. $^{18}$

We must add that, in the Greek-Roman world, sacrifices were carried out at an altar that had to be situated where the presence of a deity was imagined to be: a temple or a sacred place within the domestic realm. In Jewish sacrifice, the connection between sacrifice and the place of sacrifice is equally necessary, but in this instance, there is only one place and only one temple where the presence of the divinity is believed to materialize.

\section{THE CASE OF JESUS}

\subsection{John the Baptist's criticism of Yom ha-kippurim}

Before dealing with Jesus' attitudes towards sacrifices, we must briefly focus on John the Baptist. The fact that Jesus had been baptized by John the Baptist implies that they shared some assumptions or positions. Seemingly, Jesus agreed with the Baptist's criticism of Yom ha-kippurim as an expiatory instrument of individual voluntary sins. ${ }^{19}$

18 Secondly, a ritual is never totally coherent, in the sense that it never manages to completely subject its various characteristics, and the various ritual actions it is made up of, to its systemic unity (cf Pesce 2001:138-152).

19 On Jesus' baptism (cf Crossan 1992: 227-264; Nodet-Taylor 1998:53-82; Van Iersel 1998:88-110). This critical stance with respect to Yom ha-kippurim would explain why this fundamental annual ritual was completely abandoned by Christian tradition, whereas Pesach and Shavuot were maintained and christianized. 
Indeed, the purpose of John's baptism was the remission of voluntary sins. Clearly, this kind of remission had nothing to do with the Yom ha-kippurim ritual and the killing of victims. According to the Baptist, the performance of atoning "acts of justice" brought about forgiveness of sins (paraitesis amartadon) by God himself, as well as the purification of the psyche, to quote the terms of Flavius Josephus.

John's belief was centered on another element namely immersion in water which restored agneia, i e its purity, to the body. ${ }^{20}$ He believed that through inner conversion, public confession and atonement through acts of justice, God was actually forgiving people. He believed at the same time that some kind of impurity - provoked not by contact with sources of uncleanliness, but by moral transgression - still remained in the human body. This is the reason why the body had to be immersed and purified.

In reality, as Levine (1989) has underlined, the Yom ha-kippurim ritual did not provide for a specific purification of people. John the Baptist also seems to want to make up for the absence of this ritual on people. What were important to John the Baptist were the forgiveness of voluntary sins and the purification of the body. For him, these two objectives had nothing to do with the purification of the temple places, in that they were not related to or conditioned by the purification of the temple. Whether the Temple was contaminated or not by voluntary or inadvertent sins, did not have the slightest influence on the possibility of people obtaining forgiveness and sufficient bodily purification. ${ }^{21}$

20 The sins one had to repent for were voluntary sins. The impurity removed from the body by immersion, therefore, was not an impurity acquired through physical contact with sources of impurity.

21 To say that John the Baptist had strong reservations about the Yom ha-kippurim ritual does not, however, mean to say that he was against the Temple of Jerusalem, but simply that he had entered into conflict with the institutions of the temple, as far as the aims (certainly important, but limited) which the was putting forward with his own ritual, were concerned. This goes against Taylor (1997:29-30) who argued that "we do need to see John as anti-Temple simply because he endorsed the primacy of repentance and righteousness over sacrificing in regard to atonement and forgiveness (contra Webb 1991:203-205). Jesus himself, according to Mark, advises a cleansed leper to go to the Temple and do everything in accordance with the Law (Mk 1:40-45 // Mt 8:1-4 // Lk 5:12-16); John too may have asked his disciples to act according to the Law in regard to the temple" (Taylor 1997:110-111). The sacrifices needed for the purification from leprosy had nothing to do with voluntary sin. The alternative does not concern an acceptance or otherwise a rejection of all the rituals of the Temple, but only the possible alternative between baptism of John the Baptist and the Yom ha-kippurim ritual in relation to the forgiveness of voluntary sins. At the same time, John is by no means against the Law of the Pentateuch that prescribes the Yom ha-kippurim ritual, because as we have seen there is uncertainty about how individual sins may be expiated and forgiven through that ceremony. Is 58:3-7 offered prophetic authority for the criticism of those who believed that the Kippur fasting was by itself sufficient for the remission of voluntary sins. See also Lupieri 1988. 


\subsection{Jesus' position on remission of sins}

When Jesus distances himself from John the Baptist, he presents his own view on the remission of voluntary sins (cf Pesce 2001:152-154). The Synoptic Gospels contain a series of texts in which Jesus refers to remission as essentially depending on the relation between the sinner, God, and neighbours. In Mt 6:12, one of the invocations of the Lord's Prayer says: "forgive (afes) us our debts as we also have forgiven (afekamen) our debtors" (Mt 6:12). ${ }^{22}$ According to Matthew's Gospel, Jesus himself comments on this invocation: ${ }^{23}$ "If you forgive (afete) others their trespasses, your heavenly Father also will forgive (afesei) you. But if you do not forgive (afete) others, neither will your Father forgive (afesei) your trespasses" (Mt 6:14-15) (cf Gnilka 1986:232-234). ${ }^{24}$ This explanation, which is absent in Luke's Gospel, is however found in a different form in Mark's Gospel. "Whenever you stand praying, forgive (afiete), if you have anything

22 Harrington (1991:95) affirms: "The idea of granting a release of debts appears in Deut 15:1-2", that is to say in the context of the laws on the sabbatical year. The term "debt" used by Matthew is closer to the original than the term "sin" used by Lk 11:4, and is also confirmed by the Didaché (8:2) "and forgive us our debt as we also forgive our debtors". Yet Lk 11:4 keeps the word debtors in the second part of the verse ("for we too forgive every one in debt to us"). This leads us to think that Matthew's version is nearer to the original, and that Luke corrected only one part of the invocation, without managing to entirely eliminate the metaphor debt/sin which structured it. The problem probably arose in the passage from Aramaic to Greek. The term "debt" in Aramaic, besides its socio-economic meaning, had for some time past taken on the meaning of religious sin. In Greek, on the other hand, the word "debts" could not be the vehicle for this complexity of very closely connected religious and social meanings, and the choice therefore fell on the use of the term "sins", which more clearly embodies a religious sense (cf Jeremias 1965:13-14; Gnilka 1986:224-226; 232-234). Unlike Matthew, the Didaché does not have the aorist tense "we have forgiven", but uses the present tense "we forgive", as does Luke. Gnilka attributes some significance to Matthew's use of the aorist tense. According to him, it is "an act that occurs only once, as if to say man must make the final cancellation, cancelling his debtors' debts before arriving at God's [eschatological] judgment". Lk 11:4b would have eliminated this eschatological perspective (Gnilka 1986:225).

23 These words are probably an independent saying going back to Jesus. Gnilka (1986:234) correctly recognizes that Matthew in this instance depends on an "archetype, and that Mark 11:25 is a parallel to this saying; above all he remains strictly in line with the invocation of pardon in the Lord's Prayer." Gnilka concludes, "the logion fits Jesus' message, and in its original version can be attributed to him."

24 For the social background, see Malina \& Rohrbaugh (1992:63-64): "in an honor-shame society, sin is a breach of interpersonal relations. In the Gospels the closest analogy to the forgiveness of sins is the forgiveness of debts (Matt. 6:12; see Luke 11:4), an analogy drawn from pervasive peasant experience. Debt threatened loss of land, livelihood, and family. It impoverished people rendering them unable to maintain their social position. Forgiveness would thus have had the character of restoration, a return to both self-sufficiency and one's place in the community. Since the introspective, guilt-oriented outlook of industrialized societies did not exist, it is unlikely that forgiveness meant psychological healing. Instead, forgiveness by God meant being divinely restored to one's position and therefore being freed from fear of loss at the hands of God. Forgiveness by others meant restoration to the community. Given the antiintrospective attitude of Mediterranean people, 'conscience' was not so much an interior voice of accusation as an external one - what the neighbours said, hence blame from friends, neighbours, or authorities (cf 1 Cor 4:4)." The commentators rightly underline Mt 6:14's affinities with Sir 28:2. 
against anyone; so that (ina) your Father in heaven may also forgive you your trespasses" $(\mathrm{Mk} 11: 25)$.

Forgiveness previously granted to others, is the sine qua non condition for obtaining remission for sin from God. In conclusion, God's forgiveness is obtained through a trilateral relation between the sinner, his neighbours and God, without any expiatory sacrificial act, without any kind of bodily humiliation or decontamination, and without Jesus having any function (cf Pesce \& Destro 1999, Destro 2001; Pesce 2001:154). Actually, in the texts mentioned, the forgiveness of sins is referred to, but Jesus' role is never mentioned (nor is the expiatory function of his death, ${ }^{25}$ his authority over forgiveness of sins, or the need for faith in him). Jesus' position not only seems to depart from the Yom ha-kippurim ritual, with the associated expiatory function of the emissary goat, fasting and other forms of humiliation, it also seems to indicate a distancing from some of John's ideas. In fact, with Jesus, purification through baptism and fasting (which John continued to believe necessary) does not appear to be significant. $^{26}$

\subsection{Jesus and the Temple of Jerusalem}

Jesus' action against merchants and moneychangers in the Temple (Mk 11:15-17), is accompanied by the claim that the Temple of Jerusalem is a "house of prayer (proseuche)" (cf Chilton 1992). Jesus' reaction presupposes that he attached importance to the Temple and defended its dignity and cultic function. ${ }^{27}$ In essence, it seems to imply that Jesus did not exclude sacrifices from the cult. ${ }^{28}$

25 As on the other hand 1 Cor 15:3 will claim: "Christ died for our sins, in accordance with the Scriptures.

26 In fact: (a) Jesus does not speak of fasting as an instrument to obtain pardon; (b) already Is 58:3-7 said that fasting had no value in obtaining forgiveness, unless there was substantial humiliation consisting of the reparation of the injustice; (c) Jesus speaks of the necessity of fasting only to ensure the efficacy of certain exorcisms (Mk 9:29); (d) in the Gospel tradition, the opposing positions of Jesus and John the Baptist are explicit on the subject of fasting (Mk 2:18-20).

27 Based on a quotation from Isaiah, Mark's phrase nonetheless confirms the Temple as the cultic place. This means that Jesus believes that the presence of God is found in the Temple and that it is the place par excellence where one can pray to, approach or get close to God.

28 The term proseuche (normally translated by "prayer") indicates an action through which one commits oneself to doing something in relation to the divinity, and can be connected to sacrifice. There is no lack of literary evidence for the use of the verb proseuchomai or euchomai in connection with sacrifices. There are those who argue that purity is strictly functional to the Temple, but Jesus does not contest the Temple itself and does not contest the rules of dietary purity (only Mark does this). 
However, we have evidence that Jesus explicitly recognizes the sacrifices of the Temple of Jerusalem. This is indicated by the fact that in Mk 1:40-44 Jesus tells the leper to: "Go and show yourself to the priest, and offer ... what Moses prescribed" (1:44). Jesus thus orders the purified leper to perform the sacrificial ritual set out in Lev 14:1-32, which prescribes the offerings of a bird, two male lambs and a female lamb. These offerings correspond to sacrifices of the asham, hattat and olah type: one important provision of the ritual requires that the bird not be sacrificed by the end of the proceedings, but be set free. This "sending away" bears some similarity with the emissary goat of the Yom ha-kippurim. In general, it shows that Jesus accepts most of the sacrificial paradigm of the Temple. In this regard, we must note that Mt 5:23-24 also implies that Jesus had never made any pronouncement against sacrifices: "If when you are bringing your gift to the altar, you suddenly remember that your brother has a grievance against you, leave your gift where it is before the altar. First go and make your peace with your brother, and only then come and offer your gift."

The fact that Jesus never explicitly declared his opposition to sacrifices ${ }^{29}$ is also demonstrated by three other passages: Mt 9:13; 12,7 and Mk 12:28-34 (see Pesce 2001:160-164). In Mt 9:13 and 12:7 the quotation from Hosea 6:6 ("I desire mercy, not sacrifice") is twice attributed to Jesus. Through synoptic comparison it emerges that this quotation in both cases is a redactional addition by Matthew. It cannot be attributed to Jesus. If Matthew (or the tradition he reflects) quotes the phrase from Hosea, it is because the theme of sacrifice was important to him (or to the tradition he reflects). There are two possible hypotheses. One is that Matthew, after the destruction of the Temple, tried to find in Jesus' words or behavior some evidence that would render sacrifices practically useless. Another is that Matthew (or the tradition he reflected),

29 Chilton (1992) has argued that Jesus was in favour of sacrifices and had a sacrificial program. However alien to our own hypotheses, this seems to be useful in some respects. Chilton (1992) underlines some of the changes that had occurred in the Temple at the time of Caiaphas, which can serve as a historical background to the episode of Jesus' throwing the merchants out of the Temple. Caiaphas's measures in the thirties, as Chilton presents them, provide a clear background within which it is possible to see Jesus as not being against the sacrificial system as such, but against the modalities this system had been subjected to in the historical moment Jesus was living and acting. Jesus was thus linked to the sacrificial system, but wanted a re-organization or a defense of the original organization of the sacrificial praxis. Moreover, Chilton considers "forgiveness" as a precondition of sacrifice: "Forgiveness is the condition in which sacrifice is rightly offered, rather than the condition of which sacrifice is remedy" (Chilton 1992:133; see also Chilton 1997). 
before the destruction of the Temple, tried to coordinate Jesus' position (on the remission of sins without sacrifices) with the sacrificial praxis common to his community.

Finally, there is the passage in Mk 12:28-34 (// Mt 22:34-40) (see Mazza 2002 on Mk 12:28-34) stating that observance of the two precepts that summarize the law (love of God and love of others) "is worth more than all whole burnt offerings or sacrifices" (Mk 12:34). Here too, the exegetical evidence is basic to any interpretation. This sentence, which is absent in Matthew, is redactional, and presupposes that Jesus was not against sacrifices, because Mark attributes it to a scribe and not to Jesus. Also in this case, Mark is not aware of any declaration of Jesus against sacrifices.

We have excluded from this analysis texts in which Jesus attributes a meaning to his impending death (including those of the Last Supper). Even independently of their dubious historicity, what emerges is a reflection of Jesus about himself and his own death, and not his ideas about Jewish sacrifices as such (even though in some of them an indirect reference is implicit).

\subsection{Jesus and forgiveness}

Finally, it is necessary to concentrate on the aspect of forgiveness, the center of Jesus' idea on the remission of sins. The Jubilee of Leviticus (to which Jesus alludes in dealing with the forgiveness of sins - see Pesce \& Destro 1999) should have been immediately preceded by the Yom ha-kippurim ritual in the Temple (Lev 25:8). The crucial fact is that, first John the Baptist and then Jesus created ritual occasions or instruments for the remission of sin which were far removed from the Temple and were performed without it. But at the same time, they looked back to ritual going on in the Temple (Yom ha-kippurim and the beginning of the Jubilee, for example). This means that their religious ideals remained in a dialectical relation with the Temple or that they were not totally independent of it.

When dealing with the problem of Jesus' attitude towards sacrifices, we have therefore to bear in mind that the textual evidence presents a complex framework. Conflicting or divergent attitudes and lines of development coexist. We have to imagine a transformative process, a passage from a system centered on the Temple, to marginal or

peripheral systems, without the disappearance of the former. For the analysis we need to look for a model that can show the simultaneous presence of contradictory or divergent tendencies. 


\section{TOWARDS MODELLING FORGIVENESS}

\subsection{Modelling as a means of understanding Jesus' attitude towards sacrifice}

An overall view of the process of modelizing may be useful to begin with. Affergan states:

Le modèle offre une lecture ou une interprétation indirecte que le langage usuel ne pourrait satisfaire. Le modèle décrit indirectement, par voi métaphorique ..., ce que le langage naturel, par voi référentielle directe, ne pourrait assumer sans doute en raison de la complessité des événements humains: le vécu, la temporalité, les aspects affectifs, les énonciations, l'utilisation de déictiques ... L'observable ne l'est qu'à travers la fiction qu'en produit un modéle .... Le modèle ne copie donc pas; il ne se libre pas non plus à un pâle mimétisme du réel, mais le schématise pour en saisir des formes possibles du monde, ou plutôt des formes de mondes possibles qu'on agence ainsi mais qu'on pourrait agencer autrement. L'essentiel est de bien montrer et par voi de conséquence de bien voir .... "La pensée retentit dans le voir", nous dit Wittgenstein dans les Investigations philosophiques (II § XI). Telle est l'oeuvre que l'ethnologue doit accomplir. De même Peirce aurait vu dans la stratégie du "comme si" une des modalités de son abduction d'hypothèses, selon laquelle une hypothèse ne s'imposerait que si elle donnait une impulsion à une métamorphose de la vision en vertu de laquelle, maintenant, je vois bien une figure, un schéma grâce à cette nouvelle organitation des données.

(Affergan 1997:44, 61) ${ }^{30}$

30 "The model offers a reading or an indirect interpretation which ordinary language could not satisfy. The model describes indirectly, by metaphorical means ..., that which ordinary language, by means of direct reference, undoubtedly cannot assume, given the complexity of human events: that which is lived, experienced, the temporal, emotional aspects, declarations, utilization of deictics .... The observable only becomes visible through the fiction thereof created by a model. Thus, a model does not copy, nor does it offer a pale imitation of reality, it rather organises reality so as to grasp possible forms of the world, or rather, it presents certain forms of some possible worlds which are arranged in a particular way, but which could also be arranged otherwise. It is essentially about proper presentation which in turn will result in proper observation "Thinking reverberates in the act of seeing" says Wittgenstein in Philosophical Investigation (II, $\S$ XI). Such is the task the ethnologist must accomplish. Similarly Peirce would have recognised in the "as if" strategy one of the modalities of his abduction hypothesis, in terms of which a hypothesis can only impose itself if it gives impetus to a metamorphosis of vision in terms of which I can see a figure or a pattern due to a new organisation of the given" (Affergan 1997:44. 61). 
When applied to Jesus, or at least to that part of his actions and words that we have taken into consideration, the analysis of the models or theories of sacrifice examined in the first section of this paper have a dual effect. On the one hand, some of the features of these theories do not contribute towards an understanding of Jesus' attitude. Following the Gospels' evidence, many of the fundamental aspects of these theories on sacrifice are neither explicitly nor implicitly applicable when dealing with Jesus' position on sacrifice. In this regard, we are referring to, among others, the symbolic function of the body of the sacrificial animal, to the cosmic function of the quartering (Douglas), to the renunciationbenefit mechanism (Valeri) and to the man-animal substitution of Eilberg-Schwartz. Many of these theories do not apply to Jesus, not even to those passages where Jesus clearly accepted the sacrifices of the Jerusalem Temple (Mk 1:40-44; Mt 5:23-24; Mk 12:28-34; Mt 9:13; 12:7). In his reference to sacrifices, Jesus always seems to stress aspects, which are external to the sacrificial mechanism: he speaks of sacrifice as witness, as a sign and not as an instrument.

On the other hand however, the models and theories discussed in part I are most helpful, insofar as they indicate the singular nature of what Jesus does and says. In particular, they show the link between the sacrificial system and social relationships (Malina 1993, 1996, 2001), as well as showing the relationship between such system and the organization of time and space (Malina 1993, 2001). They enable us to clarify the specific attitude of Jesus towards his culture, and to understand the religious mechanisms he actually followed. From this point of view, Malina's model allows us to see more clearly if Jesus' behaviour marks a separation from the sacrificial model (and to what extent), whether Jesus' position reveals a departure from those social relations on which sacrificial rituals were thought to be based and upon which they actually functioned.

In Malina's model, the 1st-century Jewish sacrificial system presupposes a scheme of social relations. Thus, if Jesus conceives of the remission of sins without reference to the sacrificial device, it is legitimate to wonder what social framework he had in mind.

\subsection{The custom of granting amnesty at the beginning of a reign}

It is well known that Jesus held the imminent coming of the Kingdom of God as a fundamental concept. What is important in Jesus' view is that the remission of sins is the 
first act with which God inaugurates God's kingdom. Thus, among the visions of kingship of the ancient world of influence in the Land of Israel, we must identify a principle characterizing the beginning of a reign. Of particular interest is the oriental concept of sovereignty, widespread among Egyptian kings, in which the beginning of a new reign was marked by an amnesty. The king embodied justice and his reign had to reestablish justice. The function of the amnesty was to satisfy this requirement. The cancelling of the debts of the poorest represented a temporary suspension of the law (in terms of which payment of debt was enforced), with the aim of restoring justice to the weakest (Assmann 1991:53-70). The amnesty expressed the conviction that ideal justice was superior to the mere enforcement of laws.

The prostagmata philantropa, for example, was often proclaimed by the Ptolemaic kings (for example in the second century $\mathrm{BCE}$ ) at the beginning of their reign (cf Lenger 1980). Such dispositions or arrangements consisted of an amnesty that was intended to annul fiscal crimes, especially debts. For example, in terms of this legal custom of amnesty, a person was allowed to retain his land and work it, instead of selling it because of his debts. Such amnesties clearly helped the poorer people, who were the ones most heavily in debt. An important consequence of this form of amnesty was that it actually bypassed the bureaucratic class, which was responsible for dealing with fiscal crimes, thereby creating a direct relation between king and subjects. ${ }^{31}$

Our hypothesis is that Jesus presented an image of the God of Israel as an oriental sovereign who, at the beginning of his reign, granted an amnesty to his subjects and reestablished justice by suspending laws. This interpretation seems preferable to others, because it contextualized Jesus' view in a cultural context and reveals important social relations that are implicit in remission. It should be pointed out that the prostagmata philantropa above all addressed crimes against the king. Jesus, on the other hand, seems to universalise remission, which affords a different meaning to normal interpersonal relationships.

31 These measures could also be taken during a reign after periods of serious political crises, as in the case of the native revolts of the second century in Egypt. In this case, amnesty had the intention of achieving appeasement. 
Of most relevance to our discussion is the fact that, by referring to an ideal of God-king, Jesus utilizes a typical figure of the "religions of the temple". He, however, reshaped it profoundly, and in a sense detached it from the Jerusalem Temple (even if, as we have said, the detachment was not total). In this conceptualisation God's action is not intended to guarantee hereditary or acquired roles, but to overturn the order with the aim of establishing justice. This transcends the patron-client scheme. In fact, as previously mentioned, Malina (1996) already observed how in Leviticus an evolution of the figure of God took place, as the figure in this book appears to be depicted as a king. This transition may be read in conjunction with a vision which abandoned the patronage ideal and adopted a political notion of religion at the same time.

From the texts it becomes clear that Jesus had the relation connecting king and subjects in mind and even idealized it. Fundamentally he envisaged that, after an amnesty was granted by the God-king, a process of forgiveness from one person to another followed. In Jesus' view this is a consequent and consistent process (which aspect had not been thought of in the mechanism of the oriental amnesty). For Jesus, it is this type of action by the sovereign towards his subjects (and by one person towards another) that assures people freedom and life. In this, he transfigures the social model he was using as a reference. More specifically:

- The problem of access to the divine sphere through the mechanisms of "sanctification" (cf Malina) is not evident in Jesus' position. It is precisely the issue of the institution of a new regime of relationships between God and people that emerges in Jesus. Access to God or to the sovereign is direct. The God-king interacts directly with his subjects, without the mediation of elites or of bureaucratic classes. The law, defended by the bureaucratic classes, has been suspended in the name of justice, which is held and given only by God or the sovereign (Assmann 1982).

- The typical royal decree inaugurating a reign, i.e. amnesty, in Jesus' view, is accompanied by the need for an expanded forgiveness system, -a sort of chainreaction mechanism (cf Mt 6:12.14; 18:25-35) (see Pesce \& Destro 1999) that goes back to the Jubilee notion of afesis. The word afesis translates the Hebrew 
deror and means the act of setting free, for example, those who had been reduced to slavery because of their debts (Destro \& Pesce 2000). As we have indicated, by looking back at a procedure that had its beginnings in the Temple, Jesus makes people interact with each other, without intermediatory classes (elites, priests, bureaucracy). Thus, Jesus seems to rely on a model of social reconstitution or return to an original state of parity or equality, to the utopia of the Leviticus Jubilee.

- Remission is granted by God on the basis of previous acts of forgiveness conceded by human beings (through a series of remissions from one person to the other). Indeed, Jesus has the idea of a "conditioned remission" that reactivates life and brings about vital effects. To renounce one's rights and to forgive the neighbour enables people to escape God's imminent last judgment, and therefore death. Jesus envisages (a) that the Kingdom of God is imminent; (b) that in the kingdom of God transgressions will be punished with destruction, gehinnom. There are no sacrifices for the expiation of voluntary sins. For this reason, at the start of the Kingdom of God, an amnesty should take place, allowing people to escape condemnation.

It is worth noting that in Matthew 5:23-24 the sacrificial offering that Jesus requires should occur after the reparation-reconciliation. The sacrifice corresponds to the solemn conclusion and social testimony of the resolution of conflicts. For this reason, the offering (sacrifice) is the sign of what has previously occurred and not the instrument of the transformation of the negative into the positive. Where the principle of forgiveness intervenes, the abolition or suspension of the principle of reciprocity (renunciation/benefit) also intervenes. It is not necessary to offer in order to receive. The relation "to be forgiven"/“to forgive others" substitutes the relation to offer/to receive.

In conclusion, we may express a comparison between the patron-client relationship and forgiveness as follows. With patronage it is implicit that the client is of inferior status, that he is in debt to his patron, and that the relation linking them together is asymmetrical and personal. Patronage exploits inequalities in wealth and status (Saller 1990; Wallace-Hadrill 1990). In Jesus' proposal, the forgiveness of one individual 
towards another implies a social conception which foresees the absence of debt, reconciliation, justice and equality. Forgiveness implies non-reciprocal, non-symmetrical relationships. At the general level of the community, it constitutes a remedy against dependency and inequality. The concatenation of forgiveness envisaged by Jesus has as its objective the reordering of the society of Israel.

\subsection{Transformation and relocation of two aspects of the religion of the temple}

In order to clarify Jesus' position we have to add some reflections starting with the model of the religions of "here", of "there" and of "anywhere" (Smith 2000). Smith has proposed a classification of ancient/classical and late antique religions in three forms:

- the religion of "here" or domestic religion;

- the religions of "there" or public civic and state religions;

- the religions of "anywhere", "that occupy an interstitial space between these other two loci”.

The third category includes a "variety of religious entrepreneurs, from groups (called associations) to activities (called magic)" (Smith 2000:4). Smith (2000:18) argues for "the expansion and relative prominence of the third locus (the religion of 'anywhere') in late antiquity" (Smith 2000:4-5). He believes the diffusion of the religions of "anywhere" occurs through "reconfigurations and reinterpretations of elements characterristic of the religions of 'here' and 'there'". They are not formed entirely independently, but in concomitance with the other two forms of religion.

Smith gives a series of examples of these reconfigurations of elements coming from the other two religious models. Three factors contributed to the birth of the religion of "anywhere": "A new geography, a new cosmography, and a new polity" (Smith 2000:14). The answer to the new geography was: "the association as a socially constructed replacement for the family" (Smith 2000:15). The answer to the new cosmography was a devaluing of ritual sacrifices and a greater preference for religious experiences allowing the "transcendence of earth, both as an experience and as a source 
of knowledge" (Smith 2000:16). The answer to the new polity meant that "the old forms of kingship became idealized objects of nostalgia, as in messianism" (Smith 2000:17). ${ }^{32}$

This classification can clarify many aspects of Jesus' religion, which can be identified as typical of the religions of "anywhere". Jesus is a wandering preacher and is linked to religious forms that have in common the fact of not being linked to a "particular place". Jesus is one of the "religious practitioners not officially recognized by centers of power" according to Smith (2000:13). He is nevertheless capable, as an entrepreneur of an interstitial religious form, of eroding powers of this kind. These religious practitioners "at times [they] may imitate, at other times [they] may reverse, aspects of these two other dominant forms of religion" (Smith 2000:14).

As far as the "new geography" is concerned, it has to be noted that the organization of the Jesus movement is determined by discipleship, a specific socioreligious form that can be assimilated to what Smith considers an "association". It is a social form, occupying an intermediary position between the family and the temple. This type of association can be understood as a "replacement" of the family, as a "fictive kinship", and may enter into conflict with it. In the various early Christian groups, the discipleship-family relation is actually arranged in very different ways, precisely because of the interstitial character of these kinds of association. On the other hand neither the Temple, nor the family are substituted. As far as the "new cosmography" is concerned, the sacrifices in the Temple continue to be accepted by Jesus, but they are not the most suitable instruments to achieve the most essential relationship with God. They are not those required to obtain the forgiveness of sins. Beside the ritual action in the Temple, which Jesus continues to recognize as a place where the presence of God resides, a direct contact with God is required. This can be obtained through revelation, as in the cases of John's baptism or through transfiguration. As far as the "new polity" is concerned, Jesus seems to refer to an ideal of God that appears to be rooted in "nostalgia" for a king who takes possession of his kingdom, and who takes the whole of Israel society back to an original condition of justice and equality.

32 According to Smith (2002:21-22) all three of this type of religions may be classified through two transversal categories, the religions of sanctification and those of salvation. 
Exploring the texts within which our discourse took shape, in conclusion, we may note how Jesus' position seems to recalibrate categories and ideals. Apparently, Jesus transforms and relocates two aspects of the religion of the Temple. He modifies fundamental elements with special regard to time and space. Two of the most expressive and symbolically influential aspects of the remission of sin are, in some way, fused together by Jesus. In his concept, the forgiveness of sins and a new beginning of people's lives brought about by the Jubilee can happen anywhere (not only in the Temple) and at any time (not only once a year for Yom ha-kippurim).

\section{Works consulted}

Affergan, F 1997. La pluralité des mondes: Vers une autre anthropologie. Paris: Albin Michel.

Assmann, J 1982. Politische Theologie zwischen Ägypten und Israel. Bonn: Siemens Stiftung.

Bonte, P 1993. Quand le rite dévient technique: Sacrifice et abattage rituel dans le monde musulman. Techniques et culture 5, 79-96.

Bourdieu, P [1994] 1995. Raisons pratiques. Paris: Editions du Seuil. Italian translation in 1995. Ragioni pratiche. Bologna: Il Mulino.

Brisebarre, A M 1998. La fête du mouton: Un sacrifice musulman dans l'espace urbain. Paris: CNRS Editions.

Burkert, W 1972. Homo necans: Interpretationen altgriechischer Opferriten und Mythen. Berlin-New York: De Gruyter.

Chelhod, J 1955. Le Sacrifice chez les Arabes: Recherches sur l'évolution, la nature et les fonctions des rites sacrificiels en Arabie occidentale. Paris: Press Universitaaires de France.

Chilton, B 1992. The Temple of Jesus: His sacrificial program within a cultural history of sacrifice. University Park, PA: The Pennsylvania State University Press.

Chilton, B 1997. Jesus in context: Temple, purity and restoration. Leiden: Brill. (Arbeiten zur Geschichte des Antiken Judentums und des Urchristentums XXXIX.)

Combs-Shilling, M E 1989. Sacred performances: Islam, sexuality and sacrifice. New York: Columbia University Press. 
Crossan, J D [1991] 1992. The historical Jesus: The life of a Mediterranean Jewish peasant. San Francisco: Harper.

Crossan, J D 1998. The birth of Christianity. San Francisco, CA: HarperSanFrancisco.

Destro, A 1994. La donna niddah: Ordine del corpo e ordine del mondo giudaico, in Destro, A (ed), Le politiche del corpo: Prospettive antropologiche e storiche, 87127. Bologna: Patron.

Destro, A 2001. Il dispositivo sacrificale: Strumento della morte e della vita. Annali di Storia dell'Esegesi 18, 9-46.

Destro, A \& Pesce, M 1995. Conflits et rites dans le Temple de Jérusalem d'après la Mishna: Le rite de Yom Kippur (Traité Yoma) et l'ordalie des eaux amères (Traité Sota), in Bourgeau P \& de Pury A (eds), Le Temple, lieux du conflit: Actes du colloque de Cartigny 1988, 127-137. Leuven: Editions Peeters. (Centre d'Etude du Proche-Orient Ancien, Université de Genève.)

Destro, A \& Pesce, M 1997. Antropologia delle origini cristiane. Second edition. BariRoma: Laterza. (Quadrante 78.)

Destro, A \& Pesce, M 2000. Come nasce una religione: Antropologia e esegesi del Vangelo di Giovanni. Bari-Roma:Laterza. (Percorsi 8.).

Destro, A \& Pesce, M 2001a. Forgiveness of sins without a victim and the expiatory death of Jesus: From Mt 6:12-26:28, in Baumgarten, A (ed) 2002. Sacrifice in religious experience, 151-173. Leiden, Brill.

Dorival, G 2001. Le sacrifice dans la traduction grecque de la Septante. Annali di Storia dell'Esegesi 18, 61-79.

Douglas, M 1966. Purity and danger: An analysis of pollution and taboo. London: Routledge.

Douglas, M [1993] 2001. Nel deserto. Bologna: Edizioni Dehoniane. Italian translation in 2001 from the original In the wilderness. Sheffield: Sheffield University Press.

Douglas, M 1993. The forbidden animals in Leviticus. Journal for the study of the Old Testament 59, 3-23.

Douglas, M 1996. Sacred contagion, in Sawyer J F A (ed). Reading Leviticus: A conversation with Mary Douglas. Sheffield: Sheffield Academic Press, 86-106.

Douglas, M 1998. Leviticus as literature. Oxford: Oxford University Press. 
Eilberg-Schwartz, H 1990. The savage in Judaism: An anthropology of Israelite religion and ancient Judaism. Indiana University Press: Bloomington and Indianapolis.

Gnilka, J 1986. Das Matthäusevangelium I.Teil: Kommentar zu Kap. 1, 1-13, 58. Freiburg: Herder.

Goody, J [1997] 2000. La ambivalenza della rappresentazione: Cultura, ideologia, religione. Milano: Feltrinelli. Italian translation in 2000 from the original Representation and contradictions: Ambivalence towards images, theatre, fiction, relics and sexuality. London: Blackwell.

Grottanelli, C 1988. Uccidere, donare, mangiare: Problematiche attuali del sacrificio antico, in Grottanelli, C \& Parise, N F (eds), Sacrificio e società nel mondo antico. Roma-Bari: Laterza.

Grottanelli, C 1999. Il Sacrificio. Roma-Bari: Laterza.

Harrington, D J 1991. The Gospel of Matthew. Collegeville, MN: The Liturgical Press.

Jeremias, J [1965] 1993. Il padrenostro alla luce dell'indagine moderna, in Gesù e il suo annuncio, 37-62. Brescia: Paideia. Third edition of Italian translation from original Das Vater-Unser im Lichte der neueren Forschung. Stuttgart: Calwer Verlag.

Legasse, S [1997] 2000. Marco. Roma: Borla. Italian translation in 2000 from original L'Èvangile de Marc. Paris: Cerf.

Lenger M T [1964] 1980. Corpus des ordonnances des Ptolémés. Bruxelles.

Levine, B A 1989. Leviticus Wyqr'. (The JPS Torah Commentary), Philadelphia: The Jewish Publication Society.

Lupieri, E 1988. Giovanni Battista fra storia e leggenda. Brescia: Paideia.

Malina, B J 1993. The New Testament world: Insights from Cultural Anthropology. Revised edition. Louisville, KY: John Knox Press.

Malina, B J 1996. Mediterranean sacrifice: Dimensions of domestic and political religion. Biblical Theology Bulletin 26, 26-44.

Malina, B J 2001. The New Testament world: Insights from Cultural Anthropology. Third edition revised and expanded. Louisville, KY: John Knox Press.

Malina, B \& Rohrbaugh, R 1992. Social-science commentary on the synoptic gospels. Minneapolis: Fortress Press. 
Mazza, R 2002. "Vale più di tutti gli olocausti e i sacrifici": Considerazioni intorno a Mc 12,33. Annali di storia dell'Esegesi 19 (forthcoming).

Milgrom, J 1991. Leviticus 1-16: A new translation with introduction and commentary. New York: Doubleday. (The Anchor Bible 3.)

Nodet, 亡̀ \& Taylor, J 1998. Essai sur les origines du Christianisme: Une secte éclatée, Paris: Cerf.

Pesce, M \& Destro, A 1999. La remissione dei peccati nell'escatologia di Gesù, Annali di Storia dell'Esegesi 16, 45-76.

Pesce M., 2001. Gesù e il sacrificio ebraico. Annali di Storia dell'Esegesi 18, 129-168.

Rappaport, R A 1999. Ritual and religion in the making of humanity. Cambridge: Cambridge University Press.

Smith, J Z 2000. Here, there, and anywhere. Keynote to the conference: Prayer, magic and the stars in the ancient and late antique world, University of Washington, March 3-5, 2000. Manuscript.

Stowers, S K 1995. Greeks who sacrifice and those who do not: Toward an anthropology of Greek religion, in White L M \& Yarbrough O L (eds), The social world of the first Christians: Essays in honor of W A Meeks, 294-333. Philadelphia: Fortress Press.

Taylor, J 1997. John the Baptist within Second Temple Judaism: A historical study. SPCK: London.

Valeri, V 1985. Kingship and sacrifice: Ritual and society in ancient Hawaii. Chicago: The University of Chicago Press.

Valeri, V 1994. Wild victims: Hunting as sacrifice and sacrifice as hunting in Huaulu. History of religions 24, 101-131.

Van Iersel, B 1998. Mark: Reading-response commentary. Sheffield: Sheffield Academic Press.

Webb, R L 1991. John the Baptizer: A socio-historical study. Sheffield: Sheffield Academic Press. (JSNT Supplement Series 62.) 